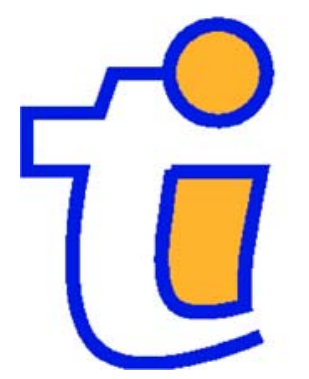

TI 2010-095/3

Tinbergen Institute Discussion Paper

Happiness and Financial Satisfaction in Israel

Effects of Religiosity, Ethnicity, and War

Bernard M.S. van Praag

Dmitri Romanov²

Ada Ferrer-i-Carbonel/3

1 University of Amsterdam, Tinbergen Institute, IZA, CESifo, DIW;

2 Central Bureau of Statistics, Jerusalem, Israel;

3 Institut d'Analisi Economica (IAE-CSIC), Barcelona, Spain, and IZA. 


\section{Tinbergen Institute}

The Tinbergen Institute is the institute for economic research of the Erasmus Universiteit Rotterdam, Universiteit van Amsterdam, and Vrije Universiteit Amsterdam.

Tinbergen Institute Amsterdam

Roetersstraat 31

1018 WB Amsterdam

The Netherlands

Tel.: +31(0)205513500

Fax: $+31(0) 205513555$

Tinbergen Institute Rotterdam

Burg. Oudlaan 50

3062 PA Rotterdam

The Netherlands

Tel.: + $31(0) 104088900$

Fax: $+31(0) 104089031$

Most TI discussion papers can be downloaded at http:/ / www.tinbergen.nl. 
Happiness and Financial Satisfaction in Israel. Effects of Religiosity, Ethnicity, and War

Bernard M.S. Van Praag*

Dmitri Romanov** Ada Ferrer-i-Carbonel1***

September 16, 2010 


\title{
Happiness and Financial Satisfaction in Israel. Effects of Religiosity, Ethnicity, and War
}

\begin{abstract}
We analyze individual satisfaction with life as a whole and satisfaction with the personal financial situation for Israeli citizens of Jewish and Arab descent. Our data set is the Israeli Social Survey (2006). We are especially interested in the impact of the religions Judaism, Islam and Christianity, where we are able to differentiate between individuals who vary in religiosity between secular and ultra-orthodox. We find a significant effect of religiosity on happiness. With respect to Jewish families it is most striking that the impact of family size on both life and financial satisfaction seems to vary with religiosity. This might be a reason for differentiation in family equivalence scales. For Arab families we did not find this effect. First-generation immigrants are less happy than secondgeneration immigrants, while there is no significant difference between second-generation families and native families. The effect of the Lebanon War is much less than expected.
\end{abstract}

Keywords: Happiness, Subjective well-being, financial satisfaction, Israel, religion, immigration, terrorism.

JEL codes: H56, I31, N35, N45, R23, Z12

* University Professor, University of Amsterdam, IZA, CESifo, DIW, Tinbergen Institute, Amsterdam, Netherlands

** Central Bureau of Statistics, Jerusalem, Israel

*** Institut D’Anàlisi Econòmica (IAE-CSIC), Barcelona, Spain and IZA 


\section{Introduction}

Since some decades happiness ${ }^{1}$ has become a subject of research for economists. The basis of this literature is the happiness or life satisfaction question in which individuals are asked to report their satisfaction with life on a bounded scale. The question is:

"On the whole, how satisfied are you with the life you are leading?"

The answer to this question, which in Israel's Social Survey ranges from 1 (very dissatisfied) to 4 (very satisfied), has been termed the individual's life satisfaction or happiness. An alternative for this question is to ask respondents to evaluate their life on a numerical scale, e.g. between 1 and 7 or 0 and 10 , instead of in verbal categories. Similar questions are posed with respect to specific aspects of life, or so-called life domains, like job satisfaction, satisfaction with respect to the respondent's financial situation, housing conditions, etc.

The responses to these questions appear to be correlated with personal characteristics of the respondents, such as age, income, past events, and their social and physical environment. We refer for surveys on this fast expanding literature to Frey and Stutzer (2002a,b), Senik (2005), Clark, Frijters, Shields (2008), Van Praag and Ferrer-i-Carbonell (2004, 2008), and Dolan, Peasgood, and White (2008). It is outside the scope of this article to give an in-depth review of the literature which is expanding at an exponential rate.

In this paper we are especially focusing on the simultaneous effects of religiosity, the impact of a war situation and the effect of the migrant status both on life satisfaction and on financial satisfaction. The latter concept comes close to the utility of income concept, while the former refers to life as whole, and may be seen as the wider concept of well-being or happiness. The effects will be different, and given the smaller and more homogeneous domain, the effects on financial satisfaction will be probably more pronounced than for life satisfaction.

The Israeli population is one of the few populations where the simultaneous effects of religiosity, the impact of a war situation and the effect of the migrant status can be observed and studied on the basis of reliable data sets. It has a mix of several religions, it lives under a war threat which is sometimes becoming reality, and a sizeable part of the population was not born in the country. Clearly there are many other countries living in comparable circumstances, but not under the

\footnotetext{
${ }^{1}$ In line with the happiness economics literature we use the words subjective well -being, happiness, and satisfaction as interchangeable.
} 
fortunate circumstance that there is a steady statistical data collection, comparable to the elaborate statistical administrations in Western countries that live under more stable conditions.

In Israel the three monotheistic religions are co-existing side by side, first Judaism - the religion of the Jewish majority, and second and third Islam and Christianity - the religions of the Arab minority. There is a small minority of Druzes. Moreover, within the two sub-populations we find a wide spectrum of religiosity, from secular through traditional and orthodox to ultra-orthodox. A sizeable part of this colorful ethno-religious mosaic consists of immigrants from all corners of the world, who make up for roughly $30 \%$ of the Jewish population.

Within the Jewish population there are three major ethnic subgroups, viz., the Jews of Ashkenazi descent (coming from European and American countries), Sephardi Jews (coming from NorthAfrican and Middle-Eastern countries), and the immigrants from the former USSR. Some families are in Israel since time immemorial, most are second-generation, and others have just recently arrived. Finally, Israel is a country where people live under a continuous threat of terrorism and warfare.

Apart from looking at the usual happiness determinants we will look at some additional factors, viz., religiosity, immigration, ethnicity, and the effects of war. In the literature there are many studies on the impact of religiosity on happiness, but most of those studies are found in the psychological and sociological journals (see Cohen (2002), Clark and Lelkes, (2005), (2009), Helliwell, (2003), Dehejia, DeLeire, and Luttmer, (2007), Heady et al. (2010), Snoep (2008)). The main result of these studies is that religiously more active persons (mostly defined in terms of church attendance) tend to be happier. These results mostly refer to Christian religions, while our study focuses mainly on Islam and Judaism, two religions that can deeply impregnate the believer's life style. Clearly, within the two religions we find a lot of gradations, ranging from ultra-orthodoxy to atheists all but in name, but it is obvious that especially for the more conservative members Islam and Judaism stand for a complex of lifestyles, ethics, and norms that deal with important issues such as one's clothing, food, time usage, obligations with respect to the family, and procreation. In our data set we have information regarding the degree of religiosity in terms of being more secular, conservative, or ultraorthodox.

Although it is mostly found that religious people are happier, Snoep (2008), for instance, finds evidence for the opposite. On the one hand, being religious and belonging to a religious group may provide a feeling of protection and safety for the individual. The religious individual mostly has a 
comprehensive vision of purpose in life, and a sense of security derived from belonging to a community, etc. On the other hand, the fact that during the 20th century the population share of religiously active citizens sharply declined in Western countries, seems to imply that many people do not see adherence to a religion as an ultimate means of achieving happiness. This observation would suggest a negative correlation between religiosity and life-satisfaction. The direction of the causality is unclear as well.

A specific issue is the role of children and family. Is their significance different for religious people than for non-religious people? Given the significance of having offspring preached by both orthodox Judaism and Islam, we expect that having children has a more positive impact on the well-being of believers than on that of non-believers. We will see that for the Jewish population this is indeed the case. The impact of having children on financial satisfaction may be considered likewise. It is wellknown that having children has a negative effect on financial satisfaction, which is easily explained by the additional cost of children (see e.g. Van Praag and Warnaar, (1993)). If having children is positively evaluated by religious persons, we may ask whether this also will be reflected in the impact of children on their financial satisfaction.

With respect to the impact of a war situation we would expect that individual life satisfaction will depend on the personal risk if one is living in a zone of warfare, on the national mood before and during the war, and, ultimately, on the war outcome. Moreover, it is plausible to expect differences in the effect of this war on life - satisfaction between Jews and Arabs.

One of the few papers on migration and happiness in the happiness economics literature is the paper by Easterlin and Plagnol (2008), which deals with the specific case of the re-unification of Germany, which is however hardly representative for migration between two different cultures. On one hand we expect that immigrants will be happy, as they compare their present situation with the past situation in their homeland. On the other hand we expect they are less happy than their new compatriots, as they struggle with adaptation problems of all sorts. The relationship between migration and mental health, which is sometimes analyzed as the reverse of happiness, has been studied as well. Most of the literature concludes that migration has a negative impact on important mental health problems, although the relation is uncertain when a broader range of mental health (e.g. depression) is included. In a recent study Stillman, McKenzie, and Gibson (2009) for the first time estimate the causal effect of migration on mental health by using information on a lottery system that randomly chooses from all the applicants the ones that are allowed to migrate from 
Tonga to New Zeeland. These authors use a measure of mental health that strongly relates to psychological well-being and thus to happiness. They conclude that migration to New Zealand improves the mental health of Tongan immigrants and that the effect is larger for women and for those with lower levels of mental health before migration.

In this study we differentiate between first- and second- generation immigrants. We differentiate with respect to origin as well. Moreover, we use for first-generation immigrants information on when they entered the country. We control for fluency in Hebrew that has been shown (e.g., Chiswick (1998), Berman et al. (2003)) to be instrumental for a successful integration into the Israeli labor market.

The effect of terrorism on happiness has been studied by Frey, Luechinger, and Stutzer (2007, 2009) and Romanov, Zussman and Zussman (2010). Frey et al. (2009) use the life satisfaction approach to assess the costs of terrorism in France, the United Kingdom, and the Republic of Ireland; Frey et al. (2007) analyze the Northern Ireland case, while Romanov et al. (2010) study the effect of the 'intifada' (that took place in 2001-2004) on happiness of Israelis. Evidently, there are all kinds of terrorism. During the period studied by us (year 2006) there was one major event, the Second Lebanon War, which was particularly threatening for the northern region of the country. The difference between the 'intifada' and the Lebanon war is that in the first instance the trouble was caused by sporadic terror attacks carried out by Palestinians across Israel over the period of four years, while in the case of the Lebanon war it was a cross-border clash between the state of Israel and a rather well-organized foreign Hezbollah army that bombarded Northern Israel intensively during 34 days. In our empirical analysis we focus on the possible effect of the Lebanon war and ignore other minor incidents. Since the interviews have been dated per day, we can follow the immediate impact of such a short war and its evolution over time. However, as the chances of the war vary from day to day the war effect on happiness varies also from day to day. It is not monotonic with the number of days elapsed. Ideally, we should have as explanatory variable a daily 'war success' or, adversely, 'war damage' index, which we do not have at our disposal. In this paper, and following up on Romanov et al. (2010), we study the impact of the Lebanon war on satisfaction with 'life as a whole' and on financial satisfaction, i.e., satisfaction with one's economic situation in Israel. 


\section{Empirical strategy.}

There are various ways to estimate the effects we look for. The usual way in order to disentangle the various effects is to use Ordered Probit or OLS. Let the response categories to the satisfaction question be denoted by $j=1, \ldots J$ and let the explanatory variables be denoted by the vector $X=\left(X_{1}, \ldots, X_{M}\right)$. The response by individual $n$ is denoted by $j_{n}$. Then the model may be written as

$$
S_{n}=\beta_{1} x_{1 n}+\ldots+\beta_{M} x_{M n}+\beta_{o}+\varepsilon_{n}
$$

where $S_{n}$ stands for the satisfaction value assigned to category $j_{n}$ and where $\varepsilon$ is the usual error term. The equation is frequently estimated by simple OLS (see, for example, Luttmer (2005)), that is, $S_{n}=j_{n}$. The main question, which can be answered after estimation, is what are the 'trade-off'ratios between variables. That is, finding an answer to the question by how much we should vary $x_{2}$ in order to compensate for a change in $x_{1}$. The answer is found by solving the equation $\beta_{1} \Delta x_{1}+$ $\beta_{2} \Delta x_{2}=0$, yielding the trade-off-ratio $\beta_{1} / \beta_{2}$. If we attach no cardinal meaning to the response $j$, we may use other estimation methods than OLS as well, such as Ordered Probit or Logit analysis. As shown by Ferrer-i-Carbonell and Frijters (2004) in practice the trade-off-ratios $\beta_{1} / \beta_{2}$ do not change much. In other words, the results with respect to trade-offs are approximately method - independent (see also Van Praag and Ferrer-i-Carbonell $(2004,2008)$ ). In this paper we use the so-called POLSoperationalization (Van Praag and Ferrer-i-Carbonell (2004, 2008) and Luechinger (2009)). This method is inspired by the observation that if we use the responses 1,2,3,4 in (2.1) as the variable to be explained, the left-hand term is bounded, while the right-hand side may attain any value on the real axis. The POLS-operationalization solves this logical flaw, while retaining the handy OLSestimation method. We refer to Van Praag and Ferrer-i-Carbonell $(2004,2008)$ for a detailed description of the method, which we briefly describe here. We define for each response category $j$ its corresponding sample share $p_{j}$ (i.e. response frequencies) and define 


$$
\begin{aligned}
& \mu_{1}=-\infty \\
& \mu_{2}=N^{-1}\left(p_{2}\right) \\
& \cdots \\
& \mu_{J}=\infty
\end{aligned}
$$

Using these $\mu$ values, we transform the satisfaction variable into

$$
\tilde{S}_{n}=E\left[u \mid \mu_{j_{n}-1}<u \leq \mu_{j_{n}}\right]=\frac{n\left(\mu_{j_{n}-1}\right)-n\left(\mu_{j_{n}}\right)}{N\left(\mu_{j_{n}}\right)-N\left(\mu_{j_{n}-1}\right)}
$$

where we set the variable to be explained equal to its conditional expectation (see e.g. Maddala, 1983), and, where $j_{n}$ stands for the response of individual $n$, and $N($.$) and n($.$) stand for the standard$ normal distribution and density function respectively. This transformation maps rare extreme events into large tail values of the normal distribution.

We assume that the explanatory variables for life satisfaction and financial satisfaction are the same, although of course with different values of the effects. The choice of the variables is partly standard, except for some variables, especially relevant for the subject of this study, which are specific for the Israeli context and this sample. It should be noticed that financial satisfaction has been rarely investigated in the happiness economics literature, except in the older studies of the Leiden School (see e.g. Van Praag, (1985) for a survey of old results).

As standard in the literature, we include ln (gross household income), both $\ln ($ age) and its square, education dummies, dummies for family status, and employment status. In most literature the age variables measured in years are added, but given a general Weber-Fechner Law, we prefer the logversion. The phenomenon that well-being is parabolic in age or log-age with a minimum at about the age of 40 has been described by Blanchflower and Oswald (2008) and earlier for financial satisfaction by Plug and Van Praag (1995). In Van Praag and Ferrer-i-Carbonell (2004) this phenomenon was shown to hold not only for life satisfaction but for almost all domain satisfactions with the exception of health. We also include family size. Intuition suggests that having to support more children implies less financial satisfaction ${ }^{2}$. Whether this effect holds for life satisfaction remains to be seen.

\footnotetext{
${ }^{2}$ We assume here that children are not used to a considerable extent in family firms, or household production, or have to contribute their earnings to the household income.
} 
Apart from the usual variables we also experiment with a variable indicating the individual selfreported health status. This variable HEALTH is operationalized in the regressions by the POLSdevice as well (see Table 1b). The advantage of using the POLS- approach for ordinal categorically defined explanatory variables is that we do not need to include four or three dummy variables, corresponding to each separate health level. However, we are a bit prudent, because subjective Health Satisfaction and Life Satisfaction might be correlated via omitted variables within the error terms, yielding an endogeneity bias ${ }^{3}$. Therefore, we present the estimation results both with and without the health-variable. Comparing coefficients between the two estimation models we do not believe that the bias mentioned is present to a significant extent, and health proves to have a considerable explanatory value per se. Another problem with 'Health' is of course that it is strongly age-related and as a consequence it may weaken the effects of age and of family size, which are age-related as well. For our data set this appears to pose no serious problem either.

\section{Religion and religiosity}

The special features of this paper are religion, immigrant status and war threat. We distinguish between Jews, Muslims, Christians, Druze and other religions. Not surprisingly, this Israeli sample contains a majority of Jews but also a fair number of Arab Muslims and Arab Christians. All respondents were not only asked for their religion (including being atheist) but also about the intensity of their religious feelings. For Jews this was done on a five-degree scale, ranging from secular to ultra-orthodox, while for Arabs the same question was asked on a four-degree scale, from secular to very religious ${ }^{4}$. In order to take account of the differences in religiosity we apply again a POLS-transformation which leads to the values as given in Table 1a. Again, the advantage of using the POLS-approach is that we do not need to include four or three dummy variables for Jews/Arabs in the regression, but that instead we can summarize religiosity by one variable. The result is the variable RELIGIOSITY.

Additionally to the general variable RELIGIOSITY, we include for the Arab sub-sample dummy variables for Christian Arabs and Druze, while Muslim Arabs are the control group.

\footnotetext{
${ }^{3}$ For a more sophisticated approach to this problem see Van Praag, Frijters, and Ferrer-i-Carbonell (2003).

${ }^{4}$ This incongruity is a bit unfortunate, but the present authors were not involved in creating the questionnaire.
} 
Table 1a. Distribution of religiosity, by ethnic group

\begin{tabular}{|l|l|l|l|l|l|}
\hline \multicolumn{1}{|c|}{ Response categories } & \multicolumn{2}{c|}{ Jews } & Response categories & \multicolumn{2}{c|}{$\begin{array}{c}\text { Arabs (Muslim, } \\
\text { Christian, Druze, } \\
\text { Other) }\end{array}$} \\
\hline $\begin{array}{l}\text { Do you consider } \\
\text { yourself as being: }\end{array}$ & $\begin{array}{l}\text { POLS } \\
\text { values }\end{array}$ & $\begin{array}{l}\text { Fraction } \\
\text { of total } \\
\text { sample }\end{array}$ & $\begin{array}{l}\text { Do you consider } \\
\text { yourself as being: }\end{array}$ & $\begin{array}{l}\text { POLS } \\
\text { values }\end{array}$ & $\begin{array}{l}\text { Fraction } \\
\text { of total } \\
\text { sample }\end{array}$ \\
\hline $\begin{array}{l}\text { Non-religious, secular or } \\
\text { atheist }\end{array}$ & -0.8808 & 0.374 & Non-religious & -1.2609 & 0.043 \\
\hline $\begin{array}{l}\text { Traditional not so } \\
\text { religious }\end{array}$ & 0.1857 & 0.205 & Not so religious & -0.3118 & 0.042 \\
\hline Traditional-religious & 0.7245 & 0.113 & Religious & 0.6426 & 0.073 \\
\hline Religious & 1.1910 & 0.081 & Very religious & 1.9818 & 0.010 \\
\hline Ultra-orthodox & 1.9148 & 0.059 & & & \\
\hline
\end{tabular}

Table 1b. Distribution of health status, by ethnic group

\begin{tabular}{|l|l|l|l|l|}
\hline \multirow{2}{*}{ Response categories } & \multicolumn{2}{|c|}{ Jews } & \multicolumn{2}{c|}{$\begin{array}{c}\text { Arabs } \\
\text { (Muslim, Christian, Druze, Other) }\end{array}$} \\
\cline { 2 - 5 } & POLS values & $\begin{array}{l}\text { Fraction of } \\
\text { total sample }\end{array}$ & POLS values & $\begin{array}{l}\text { Fraction of } \\
\text { total sample }\end{array}$ \\
\hline Health is not good at all & -1.9590 & 0.053 & -1.8439 & 0.014 \\
\hline Health is not so good & -1.1168 & 0.121 & -0.9990 & 0.027 \\
\hline Health is good & -0.2875 & 0.302 & -0.2800 & 0.050 \\
\hline Health is very good & 0.9177 & 0.356 & 0.8637 & 0.077 \\
\hline
\end{tabular}

Both in Judaism and Islam there is a positive attitude to having children. We quote from Genesis 1,28: "be fruitful and multiply". This suggests that the attitude of individuals with respect to family size may vary with the degree of religiosity. Therefore we do not only include the variable family size but its interaction with the variable RELIGIOSITY as well. This interaction variable may be interpreted in two ways. First, it opens room for the possibility that religious people evaluate having children differently than secular persons do. Second, it may be that individuals with children are evaluating being religious differently. For instance, in religious communities parents of many children are in higher esteem than couples without children.

It might also be surmised that every individual chooses its own religion and the degree of religiosity. In that case everybody would choose its optimal level and measuring the causal effect of religiosity on happiness would be hopeless. However, from data collected for another year, where parental religiosity was asked as well, we know that there is a strong correlation between religiosity between generations, both for Jews and Muslims. The fact that the individual's religiosity is strongly and 
positively correlated with parental religiosity reveals that the choice of living religiously or not is for many respondents more based on parental tradition than on a deliberate choice. Therefore, religiosity is very much pre-determined by parental upbringing.

\section{Immigrant status and ethnicity}

Israel is one of the countries with the highest fraction of immigrants in the world. These are for the most part Jewish immigrants, who have come from 'the four corners of the world'. The Israeli Social Survey, on which this research is based, does not cover temporary workers or non-permanent residents. Hence, for example, Palestinian commuters and Asian service personnel have been excluded.

We conjecture that immigrants adapt their norms on happiness over time to those of the natives and that the memory of their original worse situation wears out, the longer ago they have immigrated. In addition, it is well known that immigrants mostly have a hard time after arrival, as they lack fluency in Hebrew, and other skills needed; moreover, their social network tends to be much weaker than that of natives. Therefore we include a variable $\ln$ (years since immigration/age) that indicates what part of their life immigrants have already lived in Israel. For instance, an immigrant of 50 years old who is living for 20 years in the country scores a value of $\ln (20 / 50)$ on that (negative) variable. We name the variable 'YEARS IN ISRAEL' for short. The variable equals zero for natives. We notice that we neglect the fact that there is also a slight non-Jewish immigration.

Finally, we include fluency in Hebrew, the country's official language, as an explanatory variable, as this is a key to social inclusion and economic progress, not only for Jewish immigrants, but for the Arab minority as well.

We already said that immigrants were and are still coming from all over the world. Therefore, the Jewish population of Israel is not homogeneous at all. Their social status is unequal (see Rubinstein and Brenner (2009)). We will differentiate between Sephardi Jews, nearly all originating from North Africa or Asia (Asian republics of the FSU excluded), Askenazi Jews coming from Europe, from North- and Latin- America or from Australia (European republics of the FSU excluded), and Jews from the former Soviet Union (FSU). Moreover, we are able to differentiate between first- and second generation Israelis, according to where the father was born. We may assume that secondgeneration immigrants will be much more integrated and accordingly happier than first-generation immigrants. 


\section{War situation}

Unfortunately, Israel has been frequently subjected in recent history to an open war situation, at least in some Northern and Southern regions. This was also the case in 2006. In order to estimate the effect of such situations, we analyzed the 2006 sample, by dating the interviews with regard to the Lebanon War period (July 12 to August 14, 2006). We compare the responses during the war and in the after-war period (August 15, to the end of 2006, including the period of 48 days from the ceasefire to the completion of the pull-out of Israeli troops from Lebanon) to the responses before the war (January 1 to July 11). Therefore we include the logarithm of the war days at the time of the interview and its square. We take the log because we assume a habituation effect the longer the war is lasting. We admit for a log-quadratic effect as sentiments may accrue to a maximum and ebb off thereafter or inversely. For the same reason we admit for such a log-quadratic effect for the period after the ceasefire. We do this both for life and for financial satisfaction. We assumed a parabolalike effect, decreasing at first and increasing later on for the Jewish population, and the inverted U shape for the Arab population. We also include geographical dummies for the two northern regions, hardest and second-hardest hit by Hezbollah during the war.

Again it is not a priori clear whether the war situation will have a negative or positive effect on life and financial satisfaction. With respect to life satisfaction we have to be aware that, notwithstanding the physical and mental hardship during wartime, there may grow a very intense feeling of solidarity, patriotism, and togetherness in the population. It is also possible that the Israeli population is so accustomed to war, terror and a collective feeling of being threatened, that individuals have become immune for it and accept it as a matter of daily life.

\section{Inside or beyond the Green Line}

Since the 1967 war, the factual situation of East Jerusalem, West Bank (former Jordan territory), and Golan Heights (former Syrian territory) has become confused, as Israel created new settlements beyond the Green Line, the former boundary between Israel and Jordan and Syria before 1967. The Jewish inhabitants number now several hundred thousands. Many of them are strongly religious and Zionist-motivated. In the last years there is a heated debate within and outside Israel about the legitimacy of these settlements. We include a dummy 'SETTLEMENTS' for 'living beyond the Green line'. 


\section{Description of the data}

Our research is based on Israel's annual Social Survey for the year 2006, which is administered by Israel's Central Bureau of Statistics. The survey population is defined as the permanent noninstitutional population of citizens, aged 20 and older, including residents of non-custodial institutions (such as student dormitories, immigrant centers and independent living projects for the elderly). New immigrants are a part of the survey population if they have been present in Israel for at least six months.

The survey is carried out by means of computer-assisted personal interviews with an annual sample of about 7,500 people aged 20 and older, which is representative for the survey population of 4.5 million, including settlements beyond the Green Line. The interviews are conducted in Hebrew, Arabic and Russian. On average, interviewing takes 45-50 minutes and includes the core questionnaire of 100 items, gathering personal information of the respondent's household members and inquiring on living conditions, the individual's religion and degree of religiosity, employment status, household economic situation, skills and human capital, relations with family and friends, volunteering, victimization and, finally, subjective attitudes and satisfaction with various aspects of life, such as health, housing, social environment, financial situation and well-being in general. In addition, the 2006- survey includes 250-300 items of in-depth inquiry in special annual issues. Here we only use the Social Survey core questionnaire.

Israel's Social Survey is conducted throughout the year, five days a week, excluding Jewish calendar weekends at Friday and Saturday. This feature allows us to pinpoint an immediate effect of the Lebanon War that broke out on July 12, 2006 and lasted for 34 days, and its aftermath till the end of the year 2006. During the war there was no interviewing in the areas hit (variables WARZONE1 and WARZONE2), while in the rest of Israel the survey was being conducted at its usual pace.

Now we present some basic descriptive statistics of Israelis in the context of our research. To begin with, about $84 \%$ of the respondents in our sample are 'satisfied' or 'satisfied very much' with their lives; the percentage is significantly higher in the Jewish population than in the Arab population ( $86 \%$ and $78 \%$ respectively). Satisfaction with the financial situation scores only $53 \%$, being also considerably higher among the Jews than among the Arabs (56\% and $42 \%$ respectively) - see Figure 1 . 
Figure 1a. Distribution of Life Satisfaction Among Jews and Arabs, 2006

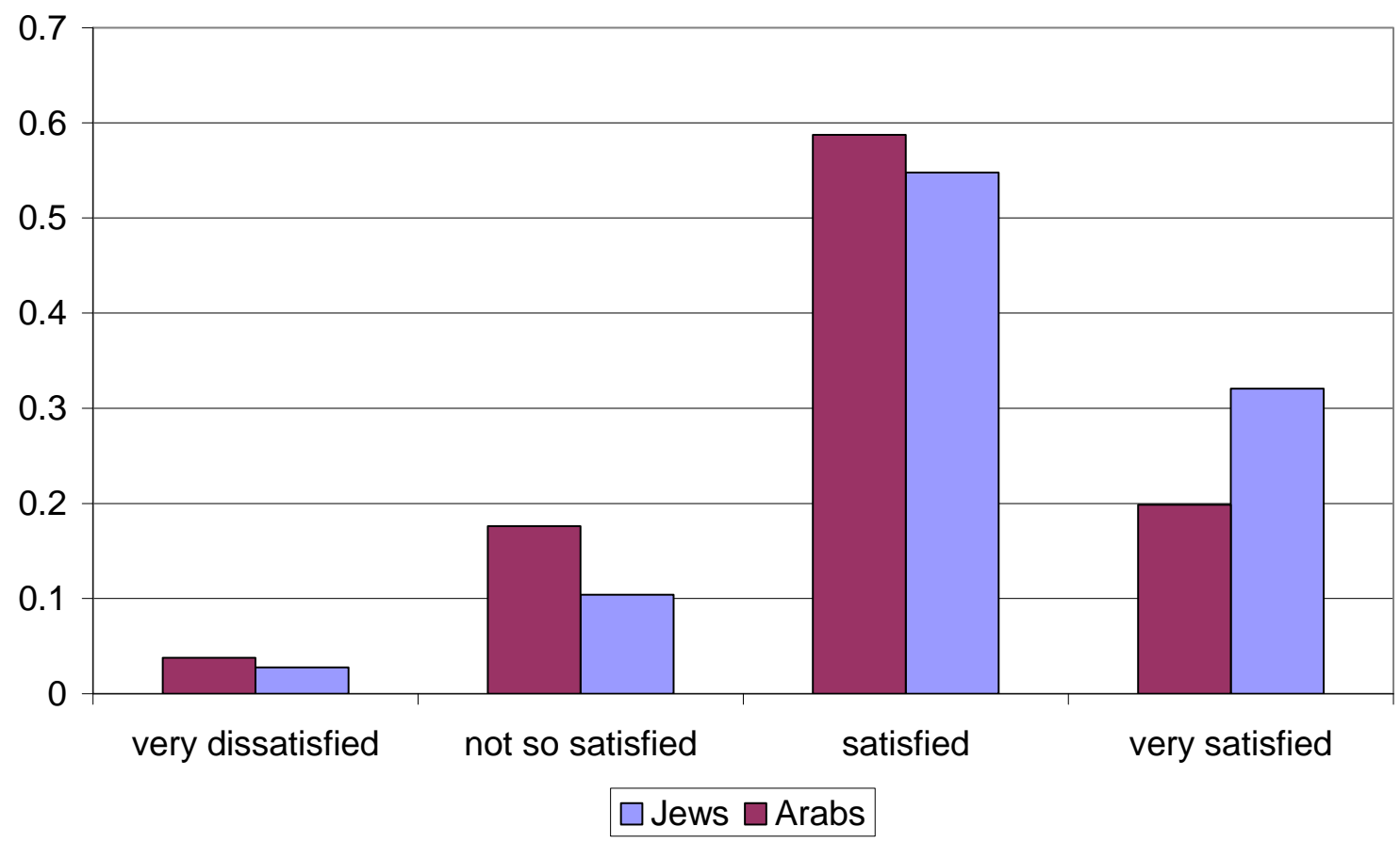


Figure 1b. Distribution of Financial Satisfaction Among Jews and Arabs, 2006

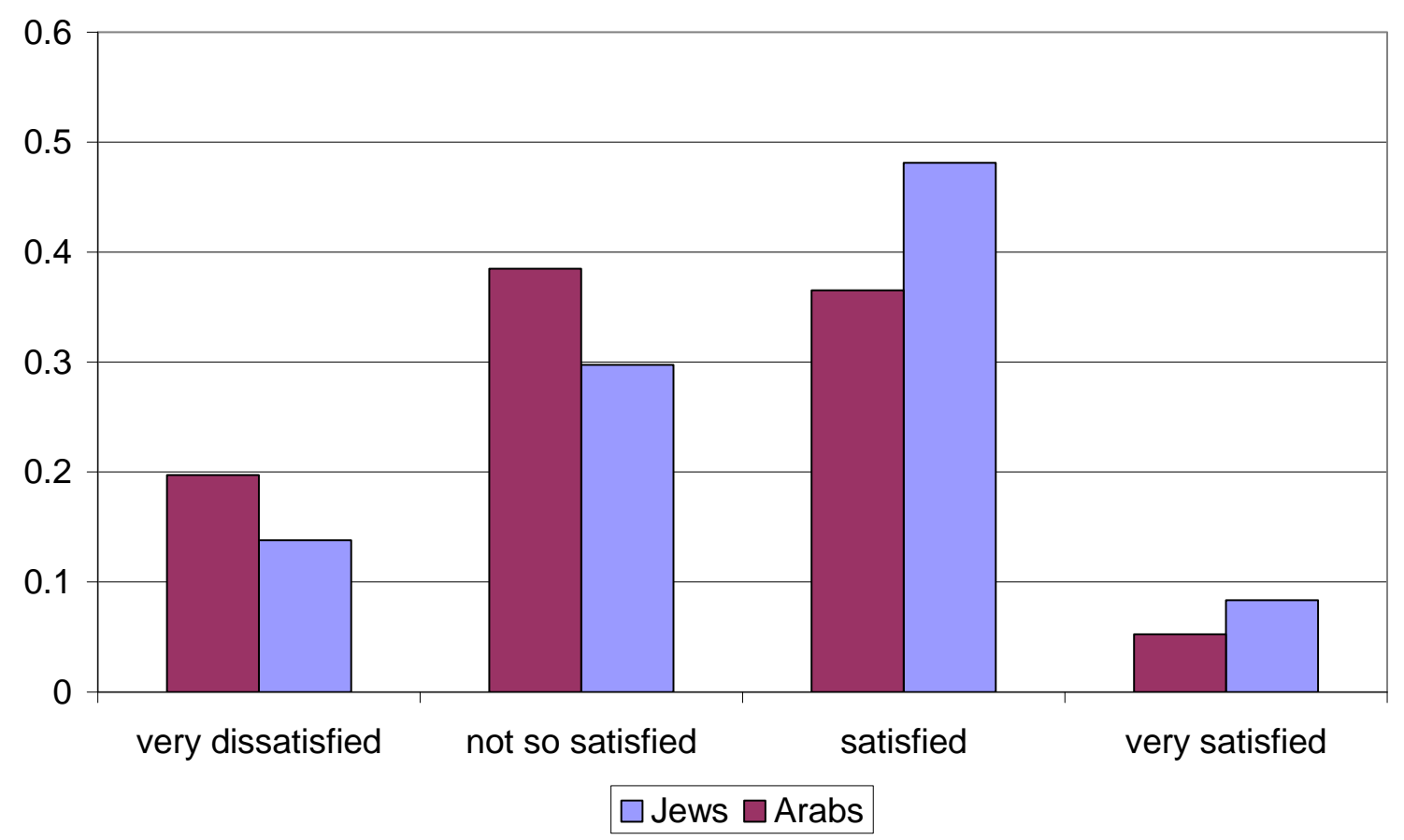

As we mentioned before, we expect religiosity to be associated with a higher fertility. This is evidently true for the Jewish population, but not for the Arab population (see Table 2). The latter phenomenon might be due to the fact that among the Muslims and the Christians religiosity on the average increases while growing older, which is not the case for the Jewish population.

Table 2. Family size and average age, by ethnic group, religion and religious intensity

\begin{tabular}{|c|c|c|c|c|c|c|c|c|c|}
\hline \multirow{2}{*}{\multicolumn{3}{|c|}{ Jews }} & \multicolumn{7}{|c|}{ Arabs } \\
\hline & & & & Muslim & & Christic & & $\begin{array}{l}\text { Druze a } \\
\text { Other }\end{array}$ & \\
\hline & $\begin{array}{l}\text { Family } \\
\text { size }\end{array}$ & Age & & $\begin{array}{l}\text { Family } \\
\text { size }\end{array}$ & Age & $\begin{array}{l}\text { Family } \\
\text { size }\end{array}$ & Age & $\begin{array}{l}\text { Family } \\
\text { size }\end{array}$ & Age \\
\hline $\begin{array}{l}\text { Non-religious, } \\
\text { secular or } \\
\text { atheist }\end{array}$ & 3.00 & 46.4 & $\begin{array}{l}\text { Non- } \\
\text { religious }\end{array}$ & 5.22 & 35.2 & 3.72 & 43.5 & 4.57 & 34.0 \\
\hline $\begin{array}{l}\text { Traditional not } \\
\text { so religious }\end{array}$ & 3.28 & 47.8 & $\begin{array}{l}\text { Not so } \\
\text { religious }\end{array}$ & 5.24 & 34.7 & 3.66 & 42.6 & 4.27 & 38.1 \\
\hline $\begin{array}{l}\text { Traditional- } \\
\text { religious }\end{array}$ & 3.58 & 48.5 & Religious & 5.09 & 42.0 & 3.56 & 50.4 & 4.57 & 48.6 \\
\hline Religious & 3.91 & 46.8 & $\begin{array}{l}\text { Very } \\
\text { religious }\end{array}$ & 4.88 & 43.9 & 2.00 & 70.0 & 4.04 & 55.2 \\
\hline Ultra-orthodox & 5.07 & 38.4 & & & & & & & \\
\hline
\end{tabular}


Table 3 presents the distribution of Jews in the Social Survey population by ethnic origin. Almost $43 \%$ of Jews aged 20 and above were born abroad, whereas the fathers of another 39\% were immigrants. Only $18 \%$ of the Jewish population aged 20 and above are at least third generation in Israel. Among Jews who are the first or the second generation in Israel, one-quarter are from the Former Soviet Union, 30\% are of Ashkenazi descent, while the rest are of Sephardic descent.

Table 3. Distribution of Jews aged 20 and above by origin and generation in Israel

\begin{tabular}{|l|c|c|}
\hline Origin & First generation in Israel & Second generation in Israel \\
\hline Former USSR & 0.179 & 0.026 \\
\hline Ashkenaz & 0.120 & 0.127 \\
\hline Sephard & 0.129 & 0.235 \\
\hline Total & 0.428 & 0.388 \\
\hline $\begin{array}{l}\text { At least third generation in } \\
\text { Israel }\end{array}$ & \multicolumn{2}{|c|}{0.184} \\
\hline
\end{tabular}

\section{Results}

As stated before, we consider two dependent variables, viz., life satisfaction and satisfaction with one's financial situation. The estimates for life satisfaction and financial satisfaction are presented in Table $4 \mathrm{a}$ and $4 \mathrm{~b}$ for Jews and Arabs, respectively

When comparing the tables we should keep in mind that the net size of the Arab sub-sample is about 1100, while the Jewish sub-sample consists of about 5100 respondents. It implies that we may expect that the 'Arab' standard deviations will be about twice as large $(\sqrt{51 / 11})$ as the 'Jewish' standard deviations.

\section{Specification}

We experimented with three specifications. The effect of age is threefold. Apart from its own effect, there is a strong connection between family size and age, as up to a certain age older people usually have more children at home than younger people. There is also a strong correlation between age and health, since health generally decreases with age. If we leave health out, we may expect that the ageeffects become more pronounced. Comparing the full specification A and specification C, without 
the health variable, we see that the exclusion of HEALTH leads indeed to the predicted effect that the other age-related coefficients become more pronounced, while the other effects do not significantly change. We notice that this holds as well for the financial satisfaction equation. It is found both for Jews and Arabs. As Health is very significant in specification A, we choose for inclusion of Health in the final specification.

A second problem is the inclusion of $\ln ($ family size $)$. That family size is a determinant of life satisfaction and financial satisfaction is well-known (cf. Van Praag and Warnaar, 1993). However, is this effect the same for religious and non-religious individuals? The best way to get an answer is to add to the variable $\ln ($ family size $)$ an interaction variable $\ln ($ family size $) *$ RELIGIOSITY. We estimated the equation with and without this variable (spec. A and B, respectively). For the Jewish sample it turns out that the interaction variable is significant, even pushing aside the effect of the original variable RELIGIOSITY itself, while the effect of $\ln ($ family size), when comparing specification A to B, remains intact. Our conclusion is that the effect of religiosity on life and on financial satisfaction for Jews is tied up with having children and that the effect of having children differs with the degree of religiosity. For the Arab population this effect is not found.

The same model that we used for explaining life satisfaction we use for explaining the satisfaction with the individual's financial situation. We generally find the same signs. This sign correspondence is not strange, for financial satisfaction is an important component of life satisfaction, as was shown in Van Praag, Frijters, Ferrer-i-Carbonell (2003). However, most of the effects are found to be more pronounced for the evaluation of the financial situation than for life satisfaction. This is intuitively plausible as life satisfaction has a much wider coverage than asking for satisfaction with respect to the financial domain only. These quantitative differences are large enough to imply that financial satisfaction is not identical at all with life satisfaction. In the older economic literature and in a considerable part still nowadays it is tacitly assumed that there is an identity between the utility of income and life satisfaction. If we assume that the empirically observed financial satisfaction may be identified with the traditional theoretical concept of the utility of money, then this empirical observation is strong evidence that utility of income and life satisfaction are different things. For economic theory, and especially the study of inequalities and theories involving utility maximization, this has rather strong implications. We notice that this still holds when we abstain from any cardinal interpretations. The two satisfaction concepts have rather different nets of indifference curves. 
The Jewish subsample

Table 4a. Life satisfaction and financial satisfaction for Jews in Israel, 2006

\begin{tabular}{|c|c|c|c|c|c|c|}
\hline & (A) & $\begin{array}{l}\text { Life satisfaction } \\
\text { (B) }\end{array}$ & (C) & (A) & $\begin{array}{l}\text { Financial satisfaction } \\
\text { (B) }\end{array}$ & (C) \\
\hline Intercept & $\begin{array}{r}11.392^{*} \\
(1.404)\end{array}$ & $\begin{array}{r}11.004^{*} \\
(1.402)\end{array}$ & $\begin{array}{r}12.034^{*} \\
(1.458)\end{array}$ & $\begin{array}{r}12.330^{*} \\
(1.424)\end{array}$ & $\begin{array}{r}12.024^{*} \\
(1.421)\end{array}$ & $\begin{array}{r}12.800^{*} \\
(1.449)\end{array}$ \\
\hline Ln(income) & $0.159^{*}$ & $0.150^{*}$ & $0.217^{*}$ & $0.553 *$ & $0.545^{*}$ & $\begin{array}{l}(1.449) \\
0.593^{*}\end{array}$ \\
\hline & $(0.021)$ & $(0.021)$ & $(0.021)$ & $(0.021)$ & $(0.021)$ & $(0.021)$ \\
\hline Ln(age) & $-6.898^{*}$ & $-6.654 *$ & $-7.232 *$ & $-9.409^{*}$ & $-9.215^{*}$ & $-9.653^{*}$ \\
\hline & $(0.769)$ & $(0.767)$ & $(0.798)$ & $(0.779)$ & $(0.777)$ & $(0.793)$ \\
\hline$\{\operatorname{Ln}(\text { age })\}^{2}$ & $0.911^{*}$ & $0.880^{*}$ & $0.914^{*}$ & $1.282^{*}$ & $1.258^{*}$ & $1.286^{*}$ \\
\hline & $(0.103)$ & $(0.103)$ & $(0.107)$ & $(0.105)$ & $(0.104)$ & $(0.107)$ \\
\hline Ln(family size) & -0.034 & -0.021 & $-0.057^{*}$ & $-0.270^{*}$ & $-0.260^{*}$ & $-0.286^{*}$ \\
\hline & $(0.027)$ & $(0.026)$ & $(0.028)$ & $(0.027)$ & $(0.027)$ & $(0.027)$ \\
\hline Ln(family size) *RELIGIOSITY & $0.081^{*}$ & & $0.117^{*}$ & $0.065^{*}$ & & $0.091^{*}$ \\
\hline & $(0.022)$ & & $(0.023)$ & $(0.022)$ & & $(0.023)$ \\
\hline RELIGIOSITY & 0.016 & $0.113 *$ & -0.017 & 0.033 & $0.111^{*}$ & 0.010 \\
\hline & $(0.030)$ & $(0.014)$ & $(0.031)$ & $(0.030)$ & $(0.015)$ & $(0.031)$ \\
\hline Health & $\begin{array}{c}0.331^{*} \\
(0.016)\end{array}$ & $\begin{array}{c}0.336^{*} \\
(0.016)\end{array}$ & & $\begin{array}{c}0.229 * \\
(0.017)\end{array}$ & $\begin{array}{c}0.233^{*} \\
(0.017)\end{array}$ & \\
\hline Schooling BA max & -0.014 & -0.011 & 0.016 & 0.005 & 0.007 & 0.026 \\
\hline & $(0.031)$ & $(0.031)$ & $(0.032)$ & $(0.031)$ & $(0.031)$ & $(0.032)$ \\
\hline Schooling MA min & $0.057^{*}$ & $0.061^{*}$ & $0.090^{*}$ & $0.081^{*}$ & $0.085^{*}$ & $0.104^{*}$ \\
\hline & $(0.030)$ & $(0.030)$ & $(0.031)$ & $(0.030)$ & $(0.030)$ & $(0.031)$ \\
\hline Married & $0.297^{*}$ & $0.282^{*}$ & $0.321^{*}$ & $0.151^{*}$ & $0.140^{*}$ & $0.168^{*}$ \\
\hline & $(0.040)$ & $(0.040)$ & $(0.041)$ & $(0.040)$ & $(0.040)$ & $(0.041)$ \\
\hline Divorced & -0.020 & -0.030 & -0.030 & -0.080 & -0.087 & -0.087 \\
\hline & $(0.054)$ & $(0.054)$ & $(0.057)$ & $(0.055)$ & $(0.055)$ & $(0.056)$ \\
\hline Widow(er) & 0.059 & 0.042 & 0.060 & 0.068 & 0.055 & 0.069 \\
\hline & $(0.062)$ & $(0.062)$ & $(0.064)$ & $(0.062)$ & $(0.062)$ & $(0.064)$ \\
\hline Former USSR 1gen & -0.057 & -0.058 & $-0.171^{*}$ & $-0.184^{*}$ & $-0.186^{*}$ & $-0.263^{*}$ \\
\hline & $(0.054)$ & $(0.054)$ & $(0.056)$ & $(0.055)$ & $(0.055)$ & $(0.056)$ \\
\hline Former USSR 2gen & 0.034 & 0.044 & 0.002 & -0.009 & 0.000 & -0.030 \\
\hline & $(0.074)$ & $(0.074)$ & $(0.077)$ & $(0.075)$ & $(0.075)$ & $(0.076)$ \\
\hline Ashkenaz lgen & -0.087 & -0.084 & $-0.125^{*}$ & $-0.098^{*}$ & $-0.096^{*}$ & $-0.124^{*}$ \\
\hline & $(0.048)$ & $(0.048)$ & $(0.050)$ & $(0.049)$ & $(0.049)$ & $(0.050)$ \\
\hline Ashkenaz 2 gen & 0.039 & 0.038 & 0.043 & 0.046 & 0.045 & 0.048 \\
\hline & $(0.043)$ & $(0.043)$ & $(0.045)$ & $(0.044)$ & $(0.044)$ & $(0.045)$ \\
\hline Sephard 1gen & $-0.102^{*}$ & $-0.117 *$ & $-0.164^{*}$ & -0.057 & -0.069 & $-0.100^{*}$ \\
\hline & $(0.047)$ & $(0.047)$ & $(0.049)$ & $(0.048)$ & $(0.048)$ & $(0.049)$ \\
\hline Sephard 2 gen & -0.034 & -0.038 & -0.057 & 0.016 & 0.013 & 0.000 \\
\hline & $(0.038)$ & $(0.038)$ & $(0.039)$ & $(0.038)$ & $(0.038)$ & $(0.039)$ \\
\hline Years in Israel & -0.003 & -0.003 & -0.048 & $-0.102^{*}$ & $-0.102^{*}$ & $-0.132^{*}$ \\
\hline & $(0.031)$ & $(0.031)$ & $(0.032)$ & $(0.032)$ & $(0.032)$ & $(0.032)$ \\
\hline Hebrew fluency & $0.098^{*}$ & $0.100^{*}$ & $0.184^{*}$ & 0.030 & 0.031 & $0.089^{*}$ \\
\hline & $(0.023)$ & $(0.023)$ & $(0.023)$ & $(0.023)$ & $(0.023)$ & $(0.023)$ \\
\hline Employed & $-0.099^{*}$ & $-0.103 *$ & -0.021 & $-0.164 *$ & $-0.167^{*}$ & $-0.109^{*}$ \\
\hline & $(0.031)$ & $(0.031)$ & $(0.032)$ & $(0.031)$ & $(0.031)$ & $(0.031)$ \\
\hline Unemployed & $-0.305^{*}$ & $-0.312^{*}$ & $-0.270^{*}$ & $-0.370^{*}$ & $-0.375^{*}$ & $-0.345^{*}$ \\
\hline & $(0.055)$ & $(0.055)$ & $(0.057)$ & $(0.055)$ & $(0.055)$ & $(0.056)$ \\
\hline Warzone 1 & 0.050 & 0.053 & 0.041 & 0.012 & 0.014 & 0.006 \\
\hline & $(0.032)$ & $(0.032)$ & $(0.034)$ & $(0.033)$ & $(0.033)$ & $(0.033)$ \\
\hline Warzone2 & 0.028 & 0.027 & 0.029 & 0.036 & 0.035 & 0.036 \\
\hline & $(0.038)$ & $(0.038)$ & $(0.040)$ & $(0.039)$ & $(0.039)$ & $(0.040)$ \\
\hline $\operatorname{Ln}$ (war days) & -0.095 & -0.101 & -0.124 & 0.058 & 0.053 & 0.039 \\
\hline & $(0.096)$ & $(0.097)$ & $(0.100)$ & $(0.098)$ & $(0.098)$ & $(0.100)$ \\
\hline$\{\text { Ln }(\text { war days })\}^{2}$ & 0.048 & 0.050 & 0.054 & -0.009 & -0.008 & -0.005 \\
\hline & $(0.033)$ & $(0.033)$ & $(0.034)$ & $(0.033)$ & $(0.033)$ & $(0.034)$ \\
\hline Ln(after war days) & 0.012 & 0.014 & 0.024 & $0.086^{*}$ & $0.087^{*}$ & $0.094^{*}$ \\
\hline & $(0.031)$ & $(0.031)$ & $(0.033)$ & $(0.032)$ & $(0.032)$ & $(0.032)$ \\
\hline$\{$ Ln(after war days $)\}^{2}$ & -0.003 & -0.004 & -0.007 & $-0.019^{*}$ & $-0.019^{*}$ & $-0.021^{*}$ \\
\hline & $(0.007)$ & $(0.007)$ & $(0.007)$ & $(0.007)$ & $(0.007)$ & $(0.007)$ \\
\hline Settlement & $0.137^{*}$ & $0.148^{*}$ & $0.135^{*}$ & $0.108^{*}$ & $0.117^{*}$ & $0.106^{*}$ \\
\hline & $(0.064)$ & $(0.064)$ & $(0.066)$ & $(0.065)$ & $(0.065)$ & $(0.066)$ \\
\hline No. obs. & 5114 & 5114 & 5116 & 5128 & 5128 & 5130 \\
\hline Adjusted $\mathrm{R}^{2}$ & 0.2527 & 0.2509 & 0.1934 & 0.2684 & 0.2673 & 0.2413 \\
\hline
\end{tabular}

Standard deviations in parentheses. * significance at 0.05 -level. Regressions weighted by the sample weights. 
Table4b. Life satisfaction and financial satisfaction for Arabs in Israel, 2006

\begin{tabular}{|c|c|c|c|c|c|c|}
\hline \multirow{3}{*}{ Intercept } & \multicolumn{3}{|c|}{ Life satisfaction } & \multicolumn{3}{|c|}{ Financial satisfaction } \\
\hline & (A) & \multirow[t]{2}{*}{ (B) } & (C) & \multirow[t]{2}{*}{ (A) } & (B) & (C) \\
\hline & $6.534 *$ & & $5.915^{*}$ & & $9.238 *$ & $8.312 *$ \\
\hline & $(2.940)$ & $(2.908)$ & $(3.103)$ & $(2.931)$ & $(2.900)$ & $(2.997)$ \\
\hline \multirow[t]{2}{*}{ Ln(income) } & $0.148^{*}$ & $0.150^{*}$ & $0.182 *$ & $0.583^{*}$ & $0.581^{*}$ & $0.605^{*}$ \\
\hline & $(0.051)$ & $(0.051)$ & $(0.054)$ & $(0.051)$ & $(0.051)$ & $(0.052)$ \\
\hline \multirow[t]{2}{*}{ Ln(age) } & $-4.596^{*}$ & $-4.335^{*}$ & $-3.945^{*}$ & $-7.600 *$ & $-7.898 *$ & $-7.188^{*}$ \\
\hline & $(1.611)$ & $(1.593)$ & $(1.700)$ & $(1.607)$ & (1.589) & $(1.642)$ \\
\hline $\multirow{2}{*}{\text { Ln }(\text { age })}^{2}$ & $0.646^{*}$ & $0.609^{*}$ & $0.486^{*}$ & $1.039^{*}$ & $1.081^{*}$ & $0.938^{*}$ \\
\hline & $(0.220)$ & $(0.217)$ & $(0.231)$ & $(0.219)$ & $(0.216)$ & $(0.223)$ \\
\hline \multirow[t]{2}{*}{ Ln(family size) } & -0.082 & -0.085 & -0.058 & $-0.225^{*}$ & $-0.223^{*}$ & $-0.210^{*}$ \\
\hline & $(0.061)$ & $(0.061)$ & $(0.064)$ & $(0.061)$ & $(0.061)$ & $(0.062)$ \\
\hline \multicolumn{7}{|l|}{ Ln(family size) } \\
\hline \multirow[t]{2}{*}{ *RELIGIOSITY } & 0.061 & & 0.058 & -0.070 & & -0.072 \\
\hline & $(0.057)$ & & $(0.060)$ & $(0.057)$ & & $(0.058)$ \\
\hline \multirow[t]{2}{*}{ RELIGIOSITY } & 0.033 & $0.126^{*}$ & 0.039 & $0.217^{*}$ & $0.111^{*}$ & $0.220 *$ \\
\hline & $(0.092)$ & $(0.032)$ & $(0.097)$ & $(0.092)$ & $(0.032)$ & $(0.094)$ \\
\hline \multirow[t]{2}{*}{ Health } & $0.373 *$ & $0.372 *$ & & $0.236^{*}$ & $0.237^{*}$ & \\
\hline & $(0.033)$ & $(0.033)$ & & $(0.033)$ & $(0.033)$ & \\
\hline \multirow[t]{2}{*}{ Schooling BA max } & 0.038 & 0.042 & 0.045 & 0.137 & 0.133 & 0.141 \\
\hline & $(0.081)$ & $(0.081)$ & $(0.086)$ & $(0.081)$ & $(0.081)$ & $(0.083)$ \\
\hline \multirow[t]{2}{*}{ Schooling MA min } & 0.019 & 0.022 & 0.081 & 0.113 & 0.109 & 0.152 \\
\hline & $(0.091)$ & $(0.091)$ & $(0.096)$ & $(0.091)$ & $(0.091)$ & $(0.093)$ \\
\hline Married & 0.121 & 0.121 & $0.233^{*}$ & $0.171 *$ & $0.171^{*}$ & $0.242 *$ \\
\hline & $(0.082)$ & $(0.082)$ & $(0.086)$ & $(0.082)$ & $(0.082)$ & $(0.083)$ \\
\hline Divorced & -0.007 & 0.018 & 0.132 & 0.150 & 0.123 & 0.238 \\
\hline & $(0.208)$ & $(0.207)$ & $(0.219)$ & $(0.207)$ & $(0.206)$ & $(0.212)$ \\
\hline Widow(er) & 0.266 & 0.265 & $0.396^{*}$ & $0.407 *$ & $0.408^{*}$ & $0.490 *$ \\
\hline & $(0.166)$ & $(0.166)$ & $(0.175)$ & $(0.165)$ & $(0.165)$ & $(0.168)$ \\
\hline Hebrew fluency & $0.074^{*}$ & $0.074 *$ & $0.122 *$ & $0.079 *$ & $0.078 *$ & $0.109^{*}$ \\
\hline & $(0.033)$ & $(0.033)$ & $(0.035)$ & $(0.033)$ & $(0.033)$ & $(0.034)$ \\
\hline Employed & $-0.149^{*}$ & $-0.153^{*}$ & -0.067 & $-0.217^{*}$ & $-0.212 *$ & $-0.165^{*}$ \\
\hline & $(0.064)$ & $(0.064)$ & $(0.067)$ & $(0.064)$ & $(0.064)$ & $(0.065)$ \\
\hline Unemployed & -0.061 & -0.063 & 0.002 & $-0.307^{*}$ & $-0.305^{*}$ & $-0.268^{*}$ \\
\hline & $(0.118)$ & $(0.118)$ & $(0.124)$ & $(0.118)$ & $(0.118)$ & $(0.120)$ \\
\hline Warzone1 & -0.017 & -0.020 & -0.019 & -0.091 & -0.087 & -0.092 \\
\hline & $(0.081)$ & $(0.081)$ & $(0.085)$ & $(0.081)$ & $(0.081)$ & $(0.082)$ \\
\hline Warzone2 & $0.145^{*}$ & $0.140^{*}$ & $0.119^{*}$ & -0.029 & -0.023 & -0.045 \\
\hline & $(0.059)$ & $(0.059)$ & $(0.063)$ & $(0.059)$ & $(0.059)$ & $(0.061)$ \\
\hline Ln(war days) & 0.438 & 0.441 & 0.429 & $0.792 *$ & $0.789 *$ & $0.786^{*}$ \\
\hline & $(0.339)$ & $(0.339)$ & $(0.358)$ & $(0.338)$ & $(0.338)$ & $(0.346)$ \\
\hline$\{\operatorname{Ln}(\text { war days })\}^{2}$ & -0.137 & -0.138 & -0.140 & $-0.253^{*}$ & $-0.253^{*}$ & $-0.255^{*}$ \\
\hline & $(0.118)$ & $(0.118)$ & $(0.124)$ & $(0.117)$ & $(0.117)$ & $(0.120)$ \\
\hline Ln(after war days) & -0.071 & -0.069 & -0.112 & 0.011 & 0.008 & -0.015 \\
\hline & $(0.070)$ & $(0.070)$ & $(0.074)$ & $(0.070)$ & $(0.070)$ & $(0.071)$ \\
\hline$\{\operatorname{Ln}(\text { after war days })\}^{2}$ & 0.026 & 0.025 & 0.029 & 0.011 & 0.011 & 0.013 \\
\hline & $(0.016)$ & $(0.016)$ & $(0.017)$ & $(0.016)$ & $(0.016)$ & $(0.016)$ \\
\hline Christian & $0.153^{*}$ & $0.162 *$ & 0.100 & -0.091 & -0.102 & -0.125 \\
\hline & $(0.079)$ & $(0.078)$ & $(0.083)$ & $(0.078)$ & $(0.078)$ & $(0.080)$ \\
\hline Druze & $0.465^{*}$ & $0.468 *$ & $0.436^{*}$ & $0.264 *$ & $0.261 *$ & $0.246^{*}$ \\
\hline & $(0.088)$ & $(0.088)$ & $(0.093)$ & $(0.088)$ & $(0.088)$ & $(0.090)$ \\
\hline No. obs. & 1104 & 1104 & 1104 & 1105 & 1105 & 1105 \\
\hline Adjusted $\mathrm{R}^{2}$ & 0.1703 & 0.1702 & 0.075 & 0.2198 & 0.2194 & 0.1842 \\
\hline
\end{tabular}

Standard deviations in parentheses. * significance at 0.05 -level. Regressions weighted by the sample weights. 
Let us first look at the results for the Jewish sub-sample. As usual when estimating happiness equations we find sizeable income effects. For life satisfaction as a whole we find 0.159 and for financial satisfaction we have 0.553. That income is much more relevant for the financial domain than for life as a whole is evident and to be expected. The quadratic age effect is in line with the literature, being significantly parabolic. The minimum lies at about 44 years of age for life satisfaction and at about 40 for financial satisfaction.

As we already surmised before, the variable RELIGIOSITY and family size are intertwined. This result is fairly surprising, as it actually implies that children are negative factors for life satisfaction for irreligious persons, while they have a positive effect on the life satisfaction of religious people. More precisely, as RELIGIOSITY for Jews takes the values $-0.88,0.19,0.72,1.19,1.91$ from secular to ultra-orthodox, the family effect ranges from $-0.034+0.081 *(-0.88)=(-0.034-0.072)=-$ 0.106 to +0.102 for ultra-orthodox ${ }^{5}$. It implies that secular families are less happy than orthodox families with an equal number of children. Restricting ourselves to financial satisfaction the same calculations give the range $-0.270+0.065 *(-0.88)=-0.327$ to -0.146 . Again, as life satisfaction has to be seen as an aggregate of domain satisfactions, the fact that the family effect on life satisfaction is much smaller than on financial satisfaction reflects the fact that the financial costs of children are partly compensated by the pleasures children give in the non-financial domains. However, the fact remains that for the totally non-religious having children seems to diminish life satisfaction. Solving the equation $-0.034+0.081 *($ RELIGIOSITY $)=0$, we find RELIGIOSITY $=0.42$ to be the degree of religiosity, where one is indifferent for having more or less children. The value 0.42 corresponds on the 'Jewish' religiosity scale (see Table 1a) with the border line between "' traditional not so religious' and 'traditional-religious'. Needless to say that there are many more determinants for fertility behavior than religion alone. Nevertheless, the relatively small families of non-religious Jewish individuals are herewith partially explained.

From these equations we can also derive estimated subjective family equivalence scales (see Van Praag, Ferrer-i-Carbonell (2004), Van Praag,Warnaar (1993)). Let us consider, for instance, by which fraction household income $y$ has to be increased to compensate for an addition in family size of $\Delta \ln \left(f_{s}\right)$. The compensation is called just if financial satisfaction is kept constant. Assuming for simplicity RELIGIOSITY $=0$, we have to solve the equation

$$
0.55 \Delta(\ln y)-0.27 \Delta\left(\ln f_{s}\right)=0
$$

\footnotetext{
${ }^{5}$ In these calculations we ignore the non-significance of some estimates.
} 
For an addition from 2 to 3 children this implies that compensated income $y_{c o m}$ satisfies

$$
\ln \left(y_{\text {com }} / y\right)=\frac{0.27}{0.55} \ln (5 / 4)
$$

or

$$
y_{\text {com }}=(5 / 4)^{\frac{0.27}{0.55}} \cdot y=1.15 . y
$$

Hence a five-person family counts for 1.15 times a four-person family.

When we would differentiate with respect to religiosity the exponent for secular Jews would be $0.33 / 0.55=0.6$, while for the ultra-orthodox Jews we would have 0.145 . This suggests that family equivalence scales might be differentiated according to religiosity.

As frequently found, health status has a great impact on life satisfaction (see also Clark and Oswald, 1994). The effect of health on financial satisfaction is considerable as well but smaller than for life as a whole.

Schooling at the BA level has only very weak statistical significance. For Jews we find a moderate positive effect for schooling at the MA-level. The difference between employed and unemployed is rather strong. Surprisingly, the employment status scores less than the reference situation of those out of the labor market. This part of the population consists, among others, of students and full-time religious scholars and retired. Overall participation rates in Israel are significantly lower than in most OECD countries.

The marriage status is a significant source of happiness. The divorced are much less happy, while the widow and widower score in between, where 'unmarried' is the reference situation.

\section{Immigrant status}

With respect to immigration we see that all first generation immigrants are less happy than their compatriots. However, the second generation effects are all insignificant, implying that the second generation is well integrated into Israeli society.

We tried various specifications for the immigrant's assimilation process. As said before 'Years in Israel' is our natural hunch, as individuals get more integrated, the longer they are in the country. 
However, whether this effect is monotonic or not is doubtful, because many new immigrants are rather elated at first, but are faced with integration difficulties later on. Moreover, it is obvious that our differentiation between first-generation and second-generation immigrants catches already a part of the adaptation effect over time. Isolating the effect is also hampered by the inclusion of the variable 'fluency in Hebrew', which is evidently strongly correlated with the length of the stay in Israel. Finally, we ended with the specification 'Years in Israel' $=\ln (x /$ age $)$, where $x$ stands for the absolute number of years in Israel, age stands for the respondent's age, and where the log-transform stretches the variable over the real axis. The effect of 'years in Israel' is significant for financial satisfaction, but not for life satisfaction. Hebrew fluency has a strong positive effect, as expected, but more for life as a whole than for the financial situation.

The war effects on life satisfaction in the latter half of 2006 are mostly statistically insignificant. Nevertheless, it does not imply that the estimates are necessarily meaningless, but only that the sample size is insufficient to get significance. For life satisfaction we find a low for the Jewish population after about 3 days after the beginning of hostilities. After ceasefire we find a top at about 6.5 days. For financial satisfaction we find (surprisingly) a high at about day 20 after outbreak of the war and a low after ceasefire at about day 9. For financial satisfaction we find a significant logparabolic effect for after war days with a top at about 10 days after the war. Then the effect peters out. Finally the settlers seem to be much happier, both in general and with respect to their financial situation, than their Jewish compatriots within the Green Line. Here we control already for religiosity differences.

\section{Arab population}

We consider now the same equations for the Arab population. We do not repeat observations, already made for the Jewish results. The Arab estimates are about half as significant as for the Jewish sample, but this is due to the much smaller sample size, as we already predicted. Actually, some of the coefficients are non-significantly different from zero in the Arab sub-sample, while in the Jewish sub-sample they are significant. However, even for the non-significant coefficients we can see whether the estimates for Jews and Arabs are significantly different ${ }^{6}$.

\footnotetext{
${ }^{6}$ By looking at the difference, divided by the square root of the sum of the variances.
} 
As already noticed before, the role of children in Arab families seems to differ from their role in Jewish families. Their role as happiness determinant is not linked to religion. Also the (negative) impact on financial satisfaction does not differ between religious and secular people.

Jews seem to value the marital status somewhat higher than Arabs do. On the contrary, widowhood seems to be a better status in the Arab family than in the Jewish family. The jobless status seems to be less negatively evaluated among Arabs than among Jews. This may be caused by the higher official unemployment in the Arab population, reducing the stigma on unemployment. Another possible explanation of this finding is related to the fact that wages of Arabs are at average much lower than wages of Jews, whereas the compensation rates of the unemployment benefits in Israel are declining with income. That is, income loss of an average Arab unemployed is much smaller than of a Jewish unemployed citizen.

It is tempting to consider the impact of the Lebanon war on both populations. Intuition predicts that the feelings of both populations will be the opposite. Although the statistical significance of the relevant estimates is low, we see that the effects for the Arab population are much larger than for the Jewish population. For life satisfaction we find indeed opposite signs, although non-significant, but for financial satisfaction we do not. We see that the Arabic population was strongly affected during the war days and not after the war ceased. For the Jewish population it was inverse. Very much tongue in cheek during the war and significantly moved when the war ceased.

The age effects are about similar. As already said the effect of log-age is parabolic, where happiness falls until a certain age, say the 'dip-age', and rises after. Although the differences are not statistically different, the dip-age for the Jewish population lies at about 44 and for Arabs at about 35. This finding is found for the other specifications as well. It may have to do with a lower life expectancy for the Arab population ${ }^{7}$, but the data set is too small to draw significant conclusions. Finally, we see a marked difference between Arab Muslims and Christians. Christians are happier than Muslims, ceteris paribus.

Like in the case of life satisfaction, employees seem to be less satisfied with their financial situation than individuals out of the labor force (retirees, beneficiaries) For Arab families the impact of children does not vary with RELIGIOSITY as for Jewish families. The effect of children on financial satisfaction is strongly negative.

\footnotetext{
${ }^{7}$ The life expectancy of Arabs is almost five years shorter than the life expectancy of the Jews.
} 


\section{Discussion and Conclusion.}

In this paper we analyzed happiness in Israel. As such it is the second study, after Romanov et al. (2010) who focused mostly on the effect of terror attacks during the three years of Intifada (20022004), on life-satisfaction of Israelis. Partly, it replicates the now more or less traditional results, well known from the exponentially expanding literature in happiness economics. However, there are some new features in the data set that we exploited. First, we used the fact that the Israeli population is divided into two main ethnic sub-populations, viz. Jews and Arabs. The ethnic gap coincides with a religious gap between Jewish majority and Muslim and Christian minorities; hence, we cannot well ascribe the differences found to ethnic differences or to religious differences. Within all subpopulations we were able to find fine differentiations in religiosity. We saw that on the whole Muslims are less satisfied with their life than Christians, while Jews score the highest; this may have to do with the status of majority and minority as well. For both groups we find strong children effects, which are mostly negative. However within the Jewish community religious people evaluate having children differently than non-religious people. Children are less of a burden (or even a blessing) for religious Jews than for secular Jews. For the Arab population we do not find such a relation between family size and religiosity.

The second rather unique feature of Israel's society is that a sizeable part of the Jewish population consists of immigrants. We see that all first-generation immigrants are less happy than their native compatriots, but that in the second generation there is no statistically significant difference. It is also found that there is no significant difference between the Sephardis, Ashkenazis and immigrants from the former USSR, when we control for other factors. Albeit to a much smaller extent, the present immigration influx into Europe may be compared with the Israeli immigration history. Then our Israeli observations may be cause for some optimism with respect to the integration of immigrants in Europe.

Finally, we investigated the effect of the 2006 military conflict between Israel and Hezbollah on life and financial satisfaction. We found a positive effect for Arabs that petered out during the hostilities and no effect afterwards. For the Jewish population the effects were the opposite. Not much effect during the war, but a temporary positive effect after the end of the hostilities. We should take into account that the explanatory variable is the number of days during the war and after. Much better, 
but not available, would have been a kind of index variable reflecting the chances of the war in favor of or against Israel. The chances varied considerably during the period of open war, and also after the end of the hostilities. That may explain the large standard errors of the estimates, as reporting in the survey fluctuated daily with ups and downs of national mood and military fortunes and misfortunes.

It might be surmised that religion has an effect on life satisfaction but not on the narrower concept of financial satisfaction. It turns out that this is not true.

From these first results, that should be replicated for other non-western societies before generalizing, it can be derived that religion is an important and probably underestimated factor in the explanation of happiness. This suggests that for the evaluation and explanation of subjective income and wellbeing inequalities (cf. Ferrer -i-Carbonell, Van Praag (2003)) we should take differences in religion and in religiosity into account. Hebrew fluency seems very important for life quality both for Jews and Arabs, but much less so for financial satisfaction.

The results of this paper moreover show that the happiness economics methodology is perfectly applicable on non-Western societies. It would be attractive to perform a similar analysis for more countries in the Middle East. 


\section{References}

Berman, E., K. Lang and E. Siniver, 2003. Language-skill complimentarity: returns to immigrant language acquisition. Labour Economics, 10(3): 265-290.

Blanchflower, D.G. and A.J. Oswald, 2008. Is Well-Being U-Shaped over the Life Cycle? Social Science \& Medicine, 66: 1733-1749.

Chiswick, B.R., 1998. Hebrew language usage: determinants and effects on earnings among immigrants in Israel. Journal of Population Economics, 11(2): 253-271.

Clark, A.E. and A.J. Oswald, 1994. Unhappiness and unemployment. Economic Journal, 104: 648659.

Clark, A.E. and O. Lelkes, 2005. Deliver us from evil: Religion as insurance. University of Granada, Papers on Economics of Religion No 06/03.

Clark, A.E., P. Frijters, and M.A. Shields, 2008. A survey of the income happiness gradient. Journal of Economic Literature, 46: 95-144.

Clark, A.E. and O. Lelkes, 2009. Let us pray: religious interactions in life satisfaction. WP 2009-1, Paris School of Economics.

Clark, A.E., P. Frijters, and M.A. Shields, 2008. A survey of the income happiness gradient. Journal of Economic Literature, 46: 95-144.

Cohen, A., 2002. The importance of spirituality in well-being for Jews and Christians. Journal of Happiness Studies, 3: 287-310.

Dehejia, R., T. DeLeire, and E.F.P Luttmer, 2007. Insuring consumption and happiness through religious organizations. Journal of Public Economics, 91: 259-279.

Dolan, P, T. Peasgood, and M. White, 2008. Do we really know what makes us happy? A review of the economic literature on the factors associated with subjective well-being. Journal of Economic Psychology, 29: 94-122.

Easterlin R.A., and A.C. Plagnol, 2008. Life satisfaction and economic conditions in East and West Germany pre- and post-unification, Journal of Economic Behavior \& Organization, 68: 433-444 Ferrer-i-Carbonell, A. and B.M.S. Van Praag, 2003. Income Satisfaction Inequality and Its Causes. Journal of Economic Inequality, 1: 107-27

Ferrer-i-Carbonell, A. and P. Frijters, 2004. How important is methodology for the estimates of the determinants of happiness? The Economic Journal, 114: 641-659. 
Frey, B.S. and A. Stutzer, 2002a. Happiness and economics. How the economy and institutions affect well-being. Princeton University Press, Princeton: New Jersey.

Frey, B.S. and A. Stutzer, 2002b. What can economists learn from happiness research? Journal of Economic Literature, 40: 402-435.

Frey, B.S., S. Luechinger, and A. Stutzer, 2007. Calculating tragedy: Assessing the costs of terrorism. Journal of Economic Surveys, 21:1-24.

Frey, B. S., S. Luechinger and A. Stutzer, 2009. The Life Satisfaction Approach to the Value of Public Goods: The Case of Terrorism. Public Choice 138(3-4): 317-345

Headey, B., J. Schupp, I. Tucci, and G.G. Wagner, 2010. Authentic Happiness Theory Supported by Impact of Religion on Life Satisfaction: A Longitudinal Analysis with Data for Germany. The Journal of Positive Psychology, 5(1): 73-82,

Helliwell, J.F., 2003. How's life? Combining individual and national variables to explain subjective well-being. Economic Modelling 20: 331-360.

Luechinger, S., 2009. Valuing air quality using the life satisfaction approach. Economic Journal, 119: 482-515.

Luttmer, E.F.P., 2005. Neighbors as Negatives: Relative Earnings and Well-Being. Quarterly Journal of Economics, 120: 963-1002.

Maddala, G.S., 1983. Limited dependent and qualitative variables in econometrics. Cambridge University Press, Cambridge: UK.

Plug, E. and B.M.S. Van Praag, 1995. Family Equivalence Scales Within a Narrow and Broad Welfare Context. Journal of Income Distribution, 4: 171-186.

Romanov, D. Zussman, A., and N. Zussman, 2010. Does Terrorism Demoralize? Evidence from Israel. Economica, forthcoming.

Rubinstein Y. and D. Brenner, 2009. Pride and Prejudice: Evidence from the Promised Land. http://www.nber.org/ confer/2009/SI2009/LS/Rubinstein.pdf

Senik, C., 2005. What Can we Learn from Subjective Data ? The Case of Income and Well-Being. Journal of Economic Surveys, 19(1): 43-63.

Stillman, S., D. McKenzie and J. Gibson, 2009. Migration and mental health: Evidence from a natural experiment. Journal of Health Economics, 28(3): 677-687

Stutzer A. and B.S. Frey, 2010. Recent Advances in the Economics of Individual Subjective WellBeing, IZA d.p.4850. 
Van Praag, B.M.S., 1985. Linking economics with psychology an economist's view, Journal of Economic Psychology, 6: 289-311

Van Praag, B.M.S., P. Frijters, and A. Ferrer-i-Carbonell, 2003. The anatomy of subjective wellbeing. Journal of Economic Behavior \& Organization, 51: 29-49.

Van Praag, B.M.S. and A. Ferrer-i-Carbonell, 2004 (2007 revised Paperback edition). Happiness quantified: A satisfaction calculus approach. Oxford University Press, Oxford: UK.

Van Praag, B.M.S. and M.F. Warnaar, 1993. The cost of children and the use of demographic variables in consumer demand. Handbook of Population and Family Economics, in: M. R. Rosenzweig and Stark, O. (eds.), Handbook of Population and Family Economics, edition 1, volume 1 , chapter 6 , pages 241-273. 